Яковлєв П. О., кандидат юридичних наук, докторант Харківського національного університету імені В. Н. Каразіна ORCID: 0000-0003-0172-5946

\title{
СУБ'ЄКТИ ВІЙСЬКОВОГО УПРАВЛІННЯ ЯК ІНСТИТУЦІї ЗАБЕЗПЕЧЕННЯ ІНФОРМАЦІЙНОЇ БЕЗПЕКИ УКРАЇНИ
}

У статті на основі аналізу правового статусу суб'єктів військового управління України виокремлено спеціальні повноваження суб'єктів військового управління у сфері забезпечення інформаційного суверенітету України, убезпечення національного інформаційного простору від інформаційних диверсій та інших недоброзичливих дій, що можуть призвести до негативних наслідків.

Ключові слова: суб'єкти військового управління; інформація; інформаційне поле; інформаційна безпека України; інформаційний суверенітет; захист інформації.

В статье на основе анализа правового статуса субъектов военного управления Украины выделены специальные полномочия субъектов военного управления в сфере обеспечения информационного суверенитета Украины, защиты национального информационного пространства от информационных диверсий и других недоброжелательных действий, которые могут привести к негативным последствиям.

Ключевые слова: субъекты военного управления; информация; информационное поле; информационная безопасность Украины; информационный суверенитет; защита информации.

Постановка проблеми. $\mathrm{y}$ 2014 р. Україна, як ніколи раніше у новітній історії, зіштовхнулася зі значною кількістю загроз державному суверенітету, національній безпеці та обороноздатності. Зокрема, на тлі загострення військовополітичної обстановки суспільство і держава повною мірою відчули на собі наслідки негативного впливу інформаційних диверсій, інформаційних атак, цілеспрямованої дезінформації населення та інших шкідливих форм посягань на націо- нальне інформаційне середовище України. За цих умов забезпечення інформаційного суверенітету та інформаційної безпеки стало одним із найбільш актуальних завдань сучасної державної політики.

Відповідно до положень Рішення Ради національної безпеки і оборони України від 29 грудня 2018 р. «Про Доктрину інформаційної безпеки України», що введено у дію Указом Президента України № 47/2017 р., усі органи державної виконавчої влади беруть участь у розробці й реалізації 
заходів, спрямованих на забезпечення інформаційної безпеки України [1]. Проте найбільше навантаження в означеному напрямі діяльності розраховане на органи, які є суб'єктами військового управління України і виконують згідно з чинним законодавством функції із захисту національного інформаційного простору. У зв'язку 3 цим актуальним завданням юридичної науки є доктринальна розробка організаційно-правових аспектів їх функціонування як інституцій забезпечення інформаційної безпеки України.

Аналіз останніх досліджень і публікацій дає підстави констатувати, що увага вітчизняних науковців до практики забезпечення інформаційної безпеки України суб'єктами військового управління $\epsilon$ недостатньою. Ознайомлення з науковим доробком В. В. Богуцького, В. О. Верхогляда, Є. І. Григоренка, М. М. Тищенка, К. В. Тарасенко дає змогу стверджувати, що участь суб'єктів військового управління у забезпеченні інформаційної безпеки України розглядається у більшості випадків у контексті виконання загальних функцій із забезпечення національної безпеки.

Постановка завдання. Виокремити спеціальні повноваження суб'єктів військового управління у сфері забезпечення інформаційного суверенітету України та убезпечення національного інформаційного поля від інформаційних диверсій та інших дій, що можуть призвести до негативних наслідків. Охарактеризувати роль і значення органів, які реалізують державну політику у сфері забезпечення національної безпеки, обороноздатності та забезпечення правопорядку України як інституцій забезпечення інформаційної безпеки України. Визначити пріоритетні шляхи оптимізації правового регулювання участі суб'єктів військового управління України у сфері забезпечення інформаційної безпеки.

Виклад основного матеріалу. Суб'єкти військового управління $\epsilon$ невід'ємними елементами державного механізму. Основне їх завдання полягає у забезпеченні національної безпеки, обороноздатності та підтриманні належного рівня правопорядку. М. М. Тищенко та В.В.Богуцький під «суб'єктами» військового управління пропонують розуміти конкретні органи, що здійснюють військове управління, виконують управлінські функції у цій сфері та наділені для цього відповідними повноваженнями [2, с. 69]. Враховуючи значну кількість інституцій, яких за характером виконуваних функцій можна віднести до суб'єктів військового управління, ми зосередимо увагу лише тих із них, компетенція яких передбачає цілеспрямоване функціонування у напрямі забезпечення інформаційної безпеки України. Передусім це Рада національної безпеки і оборони України, Міністерство оборони України, Генеральний штаб Збройних Сил України, Державна служба спеціального зв'язку та захисту інформації, Служба безпеки України, Міністерство внутрішніх справ, Державна служба спеціального зв'язку та захисту інформації, Управління державної охорони України, розвідувальні органи.

Одним із найбільш важливих органів військового управління, який виконує функції у сфері забезпечення інформаційної безпеки держави, є РНБО. Відповідно до ст. 107 Основного Закону країни предметом відання РНБО є координація й кон- 
троль за діяльністю органів виконавчої влади у сфері національної безпеки й оборони країни [3]. Повноваження РНБО деталізуються на законодавчому рівні. Так, ст. 4 Закону України «Про Раду національної безпеки і оборони України» закріплює систему специфічних повноважень органу, які хоча і різняться між собою за предметною спрямованістю, але мають координаційний характер [4]. Зокрема, у сфері забезпечення інформаційної безпеки держави до компетенції РНБО належить:

а) збір, аналіз та забезпечення надходження необхідної інформації, iіï опрацювання і збереження, забезпечення конфіденційності її використання в інтересах національної безпеки України;

б) узагальнення інформації про потенційні і реальні загрози національним інтересам України на основі аналізу стану й тенденції розвитку подій, що відбуваються в Україні та у світі;

в) залучення до аналізу інформації посадових осіб і фахівців органів виконавчої влади, державних установ, наукових закладів, підприємств та організацій усіх форм власності.

Зміст зазначених вище функцій зводиться до забезпечення узгодженості роботи різних органів державної влади та їх структурних підрозділів як учасників національного інформаційного середовища. Завдяки функціонуванню РНБО, як зазначає К. В. Тарасенко, формуються системні й стабільні зв'язки між різними суб'єктами управління у сфері національної безпеки і оборони [5, с. 681]. У кінцевому підсумку управлінська ефективність таких зв'язків визначається ієрархічним статусом і спеціалізацією кожного органу публічного управління i, зокрема, військового, в державі.

Наступним суб'єктом військового управління, який бере участь у забезпеченні інформаційної безпеки, $\epsilon$ Міністерство оборони України. Положення ст. 15 Закону України «Про національну безпеку України» від 21 червня 2018 р. № 2469-VIII визначають, що Міністерство оборони є головним органом у системі центральних органів виконавчої влади, який компетентний формувати й реалізовувати державну політику з питань національної безпеки у сферах воєнній, оборони та військового будівництва в мирний час і в особливий період [6]. Зазначені функції передбачають широкий спектр управлінських напрямів та форм функціонування Міністерства оборони у межах забезпечення захисту державного суверенітету України, територіальної цілісності й недоторканності. У свою чергу, Положення про Міністерство оборони України, затверджене постановою Кабінету Міністрів України 26 жовтня 2014 р. за № 671, закріплює деякі повноваження інформаційного характеру [7]. Зокрема, у сфері забезпечення інформаційної безпеки України Міністерство оборони провадить розвідувальну та інформаційноаналітичну діяльність в інтересах національної безпеки та оборони держави, організовує постійний моніторинг інформаційного середовища, виявляє потенційні та реальні інформаційні загрози в сфері оборони, забезпечує впровадження й розвиток новітніх інформаційних технологій у сфері оборони.

Поряд із Міністерством оборони доцільно наголосити на повнова- 
женнях у сфері забезпечення інформаційної безпеки держави Генерального Штабу Збройних Сил України. Положенням про Генеральний штаб Збройних Сил України, яке затверджене Указом Президента України від 30 січня 2019 р. за № 23/2019, визначено, що Генеральний Штаб $є$ головним військовим органом із планування оборони держави, управління застосуванням Збройних Сил України, визначених сил і засобів інших складових сил оборони, координації й контролю за виконанням завдань у сфері оборони органами виконавчої влади, органами місцевого самоврядування та іншими складовими сил оборони [8]. У сфері забезпечення інформаційної безпеки України вказаний орган військового управління уповноважений організовувати залучення органів управління та військових частин розвідки Збройних Сил до заходів добування розвідувальної інформації, здійснювати планування інформаційних операцій Збройних Сил України, опрацьовувати інформаційно-аналітичні матеріали про Збройні Сили, організовувати використання інформаційного простору держави та впровадження інформаційних технологій у діяльність Збройних Сил України.

Окрім вказаного вище, Генеральний Штаб також організовує здійснення у Міністерстві оборони та Збройних Силах моніторингу та оцінки захищеності інформації, захист інформації та кібербезпеки в інформаційно-телекомунікаційних системах, технічного захисту інформації, контролю за станом охорони державної таємниці, захисту іншої інформації 3 обмеженим доступом, криптографічного та технічного за- хисту інформації, протидії технічним розвідкам, аудиту інформаційної безпеки у Збройних Силах, здійсненні у взаємодії 3 Державною службою спеціального зв'язку та захисту інформації України заходів щодо підготовки і застосування (використання) інформаційних систем загального доступу, телекомунікаційної мережі загального користування та загальнодержавних систем спеціального зв'язку до використання в інтересах оборони, забезпечує функціонування єдиної системи захисту інформації та кіберзахисту в інформаційно-телекомунікаційних системах Міністерства оборони і Збройних Сил, організовує секретне документальне забезпечення, кіберзахист інформаційної інфраструктури Міністерства оборони і Збройних Сил, впроваджує заходи протидії системним і масштабним діям проти інтересів України в кіберпросторі іноземними державами (групами держав), зокрема із залученням кіберпідрозділів збройних сил іноземних держав, шляхом використання спеціальних засобів (кіберозброєнь), здійснює планування та реалізацію інформаційних заходів для досягнення цілей стратегічних комунікацій в інтересах Збройних Сил, а також заходи, спрямовані на виявлення, аналіз та прогнозування потенційних інформаційних загроз, що призводять до погіршення іміджу Збройних Сил, проводить роботу із запобігання таким загрозам та їх нейтралізації та ін. Відповідно, Генеральний Штаб Збройних Сил України наділений широкою компетенцією у сфері забезпечення інформаційної безпеки держави, а особливо її військового сегмента.

Важливою також для забезпечення інформаційної безпеки Украї- 
ни $\epsilon$ діяльність Державної служби спеціального зв'язку та захисту інформації (далі - Держспецзв'язок). Основними завданнями Держспецзв'язку у сфері забезпечення захисту національного інформаційного середовища є: забезпечення функціонування й розвитку державної системи урядового зв'язку, Національної системи конфіденційного зв'язку, формування й реалізації державної політики у сферах криптографічного й технічного захисту інформації, кіберзахисту, телекомунікацій, користування радіочастотним ресурсом України, поштовим зв'язком спеціального призначення, урядовим фельд'єгерським зв'язком [9]. Для виконання зазначених завдань Держспецзв'язку наділена особливими адміністративно-юрисдикційними повноваженнями у сфері розвитку інформаційних відносин. Ми вважаємо, що найбільш вагомим із них $\epsilon$ доступ на територію і в розташування об'єктів державних органів, органів місцевого самоврядування, військових формувань, утворених відповідно до законів України, підприємств, установ та організацій незалежно від форми власності, на яких знаходяться засоби спеціального зв'язку служби, на об'єкти, державний контроль щодо яких покладено на цю службу.

Вагомий внесок у забезпечення інформаційної безпеки України вносить також і Служба безпеки України (далі - СБУ). Завданням СБУ згідно із Законом «Про Службу безпеки України» від 25 березня 1992 р. за № 2229XII $€$ захист державного суверенітету, конституційного ладу, територіальної цілісності, економічного, науково-технічного й оборонного потенціалу України, законних інтересів дер- жави і прав громадян від розвідувально-підривної діяльності іноземних спеціальних служб, посягань з боку окремих організацій, груп та осіб, а також забезпечення охорони державної таємниці [10].

Система функцій СБ у сфері забезпечення інформаційної безпеки держави є значною і охоплює здійснення інформаційно-аналітичної роботи в інтересах ефективного проведення органами державної влади та управління України внутрішньої і зовнішньої діяльності, здійснення заходів контррозвідувального забезпечення дипломатичних представництв, консульських та інших державних установ, а також заходів, пов'язаних 3 охороною державних інтересів у сфері зовнішньополітичної та зовнішньоекономічної діяльності, безпекою громадян України за кордоном, здійсненням контррозвідувального забезпечення оборонного комплексу, Збройних Сил України, інших військових формувань, дислокованих на території України, організацією контролю за додержанням порядку обліку, зберігання і використання документів та інших матеріальних носіїв, що містять службову інформацію, зібрану у процесі оперативно-розшукової, контррозвідувальної діяльності, у сфері оборони країни, сприянням у порядку, передбаченому законодавством, підприємствам, установам, організаціям та підприємцям у збереженні комерційної таємниці, розголошення якої може завдати шкоди життєво важливим інтересам України. Очевидним $є$ те, що зазначені вище напрями діяльності СБУ здійснює негласно. Тому важливим $\epsilon$, як зауважує В. О. Верхогляд, «правильне усвідомлення» сутності функцій цього орга- 
ну і практичне значення діяльності [11, c. 76].

Міністерство внутрішніх справ України (далі - МВC), у підпорядкування якого перебуває Національна поліція, також виконує низку важливих функцій, спрямованих на забезпечення інформаційної безпеки держави. Відповідно до чинного законодавства завданнями MBC $\epsilon$ виконання комплексу управлінських функцій у межах державної політики протидії злочинності та забезпечення правопорядку [12]. Така діяльність супроводжується збором, зберіганням, аналізом і використанням інформації, що становить оперативний інтерес. Крім цього, у структурі Національної поліції функціонують підрозділи кіберполіції, які фахово займаються попередженням та припиненням протиправних посягань на інформаційний простір держави, розповсюдження інформації антисоціального (в тому числі й екстремістського характеру) тощо.

Також слід додати, що через MBC України здійснюється управлінська координація ще одного суб'єкта військового управління - Державної прикордонної служби України (далі ДПС). Компетенція цього органу передбачає забезпечення недоторканності державного кордону й охорони суверенних прав України в ії виключній (морській) економічній зоні. Управління службою здійснюється Адміністрацією ДПС як центральним органом виконавчої влади, діяльність якого спрямовується й координується Кабінетом Міністрів України через Міністра внутрішніх справ. Одним із основних завдань ДПС $є$ здійснення розвідувальної, інформаційно-аналітичної й оперативнорозшукової діяльності, а також контррозвідувальних заходів в інтересах забезпечення захисту державного кордону України.

Важливу роль в управлінні процесами забезпечення інформаційної безпеки виконує Управління державної охорони України (далі УДО). Вказаний орган розрахований на розроблення й реалізацію спеціальних заходів, спрямованих на забезпечення безпеки вищих посадових осіб держави, на охорону адміністративних будівель та об'єктів органів державної влади України [13]. Серед основних повноважень УДО у сегменті роботи з інформацією слід виокремити здійснення контролю за станом технічного захисту інформації про вищих посадових осіб держави; здійснення у визначеному законом порядку гласних і негласних оперативних інформаційних заходів з метою запобігання посяганням на посадових осіб і членів їх сімей, а також на об'єкти, щодо яких здійснюється державна охорона, виявлення і припинення таких посягань.

Розглядаючи компетенцію суб'єктів військового управління у сфері забезпечення інформаційної безпеки держави, доцільно акцентувати увагу на розвідувальних органах України. Такі органи представлені Службою зовнішньої розвідки, розвідувальним органом Міністерства оборони, розвідувальним органом спеціально уповноваженого центрального органу виконавчої влади у справах охорони державного кордону України. Відповідно до Закону України «Про розвідувальні органи України» від 22 березня 2001 р. № 2331-III сферою компетенції розвідувальних органів $€$ здійснення збір розвідувальної інформації, інформаційне сприяння реалізації та 
захисту національних інтересів України, у тому числі й у кіберпросторі [14]. Розвідувальні органи функціонують негласно, набута ними інформація є стратегічним ресурсом держави, однією із гарантій національної безпеки і правопорядку.

Висновки. На сьогодні в Україні суб'єкти військового управління $€$ інституціями, які несуть основне навантаження із забезпечення інформаційної безпеки і інформаційного суверенітету держави. Порівняно із цивільними владними інституціями, суб'єкти військового управління наділені адміністративно-юрисдикційними повноваженнями, застосування яких дає їм змогу більш оперативно реагувати на ризики і загрози національному інформаційному середовищу. Важливою особливістю компетенції у сфері забезпечення інформаційної безпеки суб'єктами військового управління $\epsilon$ те, що фун- кції і повноваження інформаційного характеру здійснюються кожним із них у межах реалізації власної предметної компетенції відповідно до мети діяльності. У додаток до цього, зміст повноважень у сфері забезпечення інформаційної безпеки України багатьох органів $\epsilon$ схожим, що призводить до дублювання функцій. Це спонукає до формування законодавчих пропозицій щодо впровадження організаційно-правових механізмів їх розмежування. Також недоліком нормативного забезпечення повноважень у сфері інформаційної безпеки силовим блоком держави можна вважати дефіцит юридичних підстав взаємодії з цивільними органами влади й інституціями громадянського суспільства. Саме цей аспект має стати одним із пріоритетних напрямів дослідження сучасної юридичної науки.

\section{Список використаних джерел}

1. Про рішення Ради національної безпеки і оборони України від 29 грудня 2016 року «Про Доктрину інформаційної безпеки України» : Указ Президента України від 25.02.2017 р. № 47/217. Офіційний вісник Президента України. 2017. № 5. С. 15.

2. Тищенко М. М., Богуцький В. В., Григоренко Є. І. Військова адміністрація : навч. посіб. / за заг. ред. М. М. Тищенка. 2-ге вид., переробл. та доп. Харків : Право, 2014. 364 c.

3. Конституція України : офіц. текст. Київ : Алерта, 2019. 80 с. Ст. 141.

4. Про Раду національної безпеки і оборони України: Закон України від 05.03.1998 р. № 183/98-ВР. Відомості Верховної Ради України. 1998. № 35. Ст. 237.

5. Тарасенко К. В. Компетенція, форми і методи діяльності та відповідальність Ради національної безпеки і оборони України. Форум права. 2012. № 2. С. 681.

6. Про національну безпеку України: Закон України від 21.06.2018 р. № 2469VIII. Відомості Верховної Ради України. 2018. № 31. Ст. 241.

7. Про затвердження Положення про Міністерство оборони України. постанова Кабінету Міністрів України від 26.11.2014 р. № 671. Офіційний вісник України. 2014. № 97. Ст. 2796.

8. Про Положення про Генеральний штаб Збройних Сил України: Указ Президента України від 30.01.2019 р. № 23/2019. Офіційний вісник Президента України. 2019. № 13. Ст. 468. 
9. Про Державну службу спеціального зв'язку та захисту інформації України: Закон України від 23.02.2006 р. № 3475-IV. Відомості Верховної Ради України. 2006. № 30. Ст. 258.

10. Про Службу безпеки України: Закон України від 25.03.1992 р. № 2229-XII Відомості Верховної Ради Украӥни. 1992. № 27. Ст. 382.

11. Верхогляд В. О. Пріоритетні функції і повноваження СБУ та їх співвідношення у взаємодії зі структурами громадянського суспільства. Вісник Харківського національного університету внутрішніх справ. 2010. № 4 (51). Ч. 2. С. 75-80.

12. Про затвердження Положення про Міністерство внутрішніх справ України: постанова Кабінету Міністрів України від 28.10.2015 р. № 878.

13. Про державну охорону органів державної влади України та посадових осіб : Закон України від 04.03.1998 р. № 160/98 - ВР. Відомості Верховної Ради України. 1998. № 35. Ст. 236.

14. Про розвідувальні органи України: Закон України від 22.03.2001 р. № 2331III. Відомості Верховної Ради України. 2001. № 19. Ст. 94.

\section{References}

1. Tishenko, M. M., Boguckij, V. V., Grigorenko, Ye. I. (2014). Vijskova administraciya: navch. posib. Harkiv: Pravo [in Ukrainian].

2. Tarasenko, K. V. (2012). Kompetenciya, formi i metodi diyalnosti ta vidpovidalnist Radi nacionalnoyi bezpeki i oboroni Ukrayini. Forum prava, 2, 681 [in Ukrainian].

3. Verhoglyad, V. O. (2010). Prioritetni funkciyi i povnovazhennya SBU ta yih spivvidnoshennya u vzayemodiyi zi strukturami gromadyanskogo suspilstva. Visnik Harkivskogo nacionalnogo universitetu vnutrishnih sprav. 2010. № 4 (51), 2, 75-80.

P. Yakovlev, Ph.D in Law, Competitor of scientific degree of V. N. Karazin Kharkiv National University

ORCID: 0000-0003-0172-5946

\section{Military authorities as institutions for ensuring information security of Ukraine}

Today in Ukraine military authorities are the institutions carrying out the main workload for ensuring information security and information sovereignty of the state. Compared to civilian authorities, military authorities are vested with administrative and jurisdictional powers that enable them to respond more quickly to the threats to the national information environment. The important feature of the competence in the field of ensuring information security by military authorities is that the functions and powers of the information character are exercised by each of them within the scope of their own substantive competence in accordance with the purpose of the activities.

In this article, on the basis of the analysis of the legal status of the military authorities of Ukraine, the special powers of the military authorities in the sphere of ensuring information sovereignty of Ukraine, of the protection of the national information space from informational sabotage and of other spiteful actions which can result in negative consequences are identified. In particular, the special powers 
in the sphere of ensuring information security of Ukraine of such bodies as the National Security and Defense Council of Ukraine, the Ministry of Defense of Ukraine, the General Staff of the Armed Forces of Ukraine, the Security Service of Ukraine, the Ministry of Internal Affairs of Ukraine, the State Service of Special Communication and Information Protection of Ukraine, the Department of the State Guard of Ukraine, intelligence agencies are provided in this article.

It is emphasized that that the scope of powers in the field of ensuring information security of Ukraine is similar for many military authorities, which leads to the duplication of functions. Accordingly, it is advisable to formulate legislative proposals to introduce organizational and legal mechanisms for their delimitation. It is also substantiated that it is rational to expand the legal basis for the interaction of military authorities with civilian authorities and civil society institutions in the process of fulfilling the tasks for ensuring information security of the state.

Keywords: military authorities; information; information field; information security of Ukraine; information sovereignty; information protection; state policy. 